\title{
MONITOROVÁNí ÚČINNOSTI V PSYCHOTERAPII A PORADENSTVÍ1,2
}

\author{
TOMÁš ŘIHÁČEK
}

\begin{abstract}
Abstrakt: Ve výzkumu psychoterapie a poradenství se v posledních letech prosazuje tzv. na praxi orientovaný výzkum, jehož cílem je zkoumat proces a efekt psychoterapeutických a poradenských intervencí $\mathrm{v}$ podmínkách běžné praxe. V terapeutických a poradenských zařízeních v západním světě se stále častěji začínají používat softwarové systémy průběžně monitorující efekt nabízené péče. Výzkumy ukazují, že používání zpětnovazebních informací z těchto systémů má pozitivní vliv na účinnost terapeutické a poradenské praxe. $V$ tomto př́spěvku budou nastíněny principy fungování těchto systémů a dále budou shrnuty př́nosy i limity rutinního monitorování účinnosti a jeho implementace do praxe.
\end{abstract}

Klíčová slova: účinnost psychoterapie, monitorování účinku, zpětná vazba, implementace

Účinnost psychoterapie je dnes již považována za spolehlivě prokázanou (Lambert, 2013b; Wampold, 2001). Od doby prvních metaanalýz (Glass \& Smith, 1977; Glass, Smith, \& Miller, 1980) byly publikovány stovky metaanalytických studií i metaanalýzy těchto metaanalýz (např. Lipsey \& Wilson, 1993), z jejichž výsledků je zřejmé, že klienti z psychoterapeutických intervencí v průměru významně profitují. To však neznamená, že všichni profitují stejně a že výsledek je u všech klientů podobně optimistický. Ukazuje se, že značný podíl klientů se v průběhu terapie nezlepšuje a část se jich dokonce zhoršuje (Lambert, 2013b).

Účinnost terapie se také liší podle toho, zda je zkoumána v experimentálních studiích (randomized clinical trial, RCT), které jsou přísně kontrolované, v nichž se terapie řídí předepsaným manuálem, počet sezení je předem stanoven a mezi klienty nejsou zařazováni lidé, kteří nesplňují přísná diagnostická kritéria, nebo zda je zkoumána v podmínkách běžné praxe, kde je průběh terapie mnohem více variabilní - terapie je ve větší míře přizpůsobována potřebám konkrétního klienta, počet sezení je proměnlivý a klienti často splňují kritéria více diagnostických kategorií. Podle přehledové studie Hansena, Lamberta a Formana (2002) se v rámci experimentálních studií účinnosti

\footnotetext{
1 Vznik tohoto článku byl podpořen z prostředků grantových projektů GAP407/11/0141 a MUNI/A/1160/2014.

2 Příspěvek vznikl v návaznosti na konferenci Psychologická diagnostika Brno (22.-23. ř́ijen 2015).

${ }^{3}$ Katedra psychologie, Fakulta sociálních studií MU, Joštova 10, 60200 Brno
} 
vyléčilo 57,6 \% klientů a celkově 67,2 \% dosáhlo významného zlepšení. Studie, z nichž autoři vycházeli, systematicky neuváděly procento zhoršených klientů (k tomu, jak je v těchto studiích definováno vyléčení, zlepšení či zhoršení, se vrátíme níže v textu). V podmínkách běžné praxe se však podle téže studie vyléčilo průměrně necelých 14,1 \% klientů a významného zlepšení dosáhlo v průměru 20,9 \%. Průměrně 8,2 \% klientů se přitom během terapie významně zhoršilo. Za tento rozdíl může být mj. odpovědná rozdílná délka poskytnuté terapie: zatímco v experimentálních studiích činila průměrná délka terapie 12,7 sezení, v podmínkách běžné klinické praxe to bylo méně než 5 sezení.

Podle Lambertovy a Oglesovy (2004) přehledové studie existuje konzistentní podíl zhoršených klientů např́č studiemi ve výši 5-10\%. Ne ve všech případech je samozřejmě na vině samotná psychoterapeutická intervence: může se jednat např. o progres onemocnění, který terapie pouze nedokázala zastavit, nebo o vliv neočekávaných životních událostí na straně klienta (Lambert, 2013b). Řada studií nicméně ukazuje, že zhoršení může být způsobeno terapií samotnou a mluví se o tzv. deterioračním efektu (Barlow, 2010; Bergin \& Lambert, 1978). Přestože se podle uvedených statistik jedná o relativně častý jev, ukazuje se, že psychoterapeuti mají velmi nízkou schopnost včas toto zhoršování u svých klientů rozpoznat (Hannan et al., 2005; Hatfield, McCullough, Frantz, \& Krieger, 2010).

Tato zjištění představují výzvu pro psychoterapeutickou praxi. Nabízí se otázka, zda a jakým způsobem je možno podpořit schopnost psychoterapeutů včas identifikovat ty případy, v nichž hrozí, že se klienti vlivem terapie zhorší nebo předčasně terapii ukončí. Řešení nabízí monitorovací systémy, které využívají klientem vyplňovaných dotazníků ke sledování pozitivní či negativní změny během terapie (Castonguay, Barkham, Lutz, \& McAleavey, 2013; Lambert, 2013a).

\section{Systémy monitorující účinnost psychoterapie v běžné praxi}

V západním světě existuje celá řada softwarových (obvykle webových) systémů, které umožňují pohodlný sběr dat od klientů i jejich terapeutů a poskytují zpětnou vazbu o průběhu terapie u každého jednotlivého klienta, stejně jako obecnější statistiky na úrovni pracovišt'. Tyto systémy jsou založeny na klientem vyplňovaných sebeposuzovacích dotaznících vyvinutých pro měření účinku psychoterapeutických a poradenských intervencí. Klient tyto dotazníky obvykle vyplňuje nejen v rámci vstupní diagnostiky před zahájením terapie a po jejím skončení, ale také v jejím průběhu (před každým sezením). Z takto získaných dat se postupně vytváří trajektorie klientovy změny, kterou pak terapeut může sledovat. Mimo to může terapeut dostávat též upozornění v případě, že se klientova trajektorie odchyluje od očekávaného směru vývoje. Tímto způsobem systém zachytí případy, kdy se klientův stav dlouhodobě nezlepšuje či se dokonce zhoršuje, a tím sníží riziko předčasného ukončení terapie a deterioračního efektu. 
Očekávaný průběh terapie se odhaduje bud'to na základě racionálně, nebo empiricky odvozených metod (Lutz, Böhnke, \& Köck, 2011; Lutz, Stulz, Martinovich, Leon, \& Saunders, 2009). V případě racionálně odvozených metod se jedná o expertní úvahu ohledně toho, jak velká musí naměřená změna být, aby mohla být považována za dostatečnou. Obvykle se přitom vychází z konceptů klinicky významné a statisticky spolehlivé změny (Jacobson \& Truax, 1991). Klinicky významnou změnu (clinically significant change) lze definovat jako přesun klienta z dysfunkční (klinické) do zdravé (neklinické) populace, který je operacionalizován jako překročení určité hraniční hodnoty skóru v daném dotazníku. Statisticky spolehlivá změna (statistically reliable change) znamená, že daný klient vykázal změnu, jež svou velikostí přesahuje chybu měřicího nástroje. Kombinací těchto dvou údajů pak potenciálně vzniknou čtyři skupiny klientů: vyléčení (tj. ti, kteří dosáhli klinicky významné i statisticky spolehlivé změny), zlepšení (tj. ti, kteří dosáhli statisticky spolehlivé změny, ale nepřekročili hranici mezi dysfunkční a zdravou populací), nezlepšení (změna, pokud nastala, nedosáhla míry statisticky spolehlivé změny) a zhoršení (tj. ti, kteří vykázali statisticky spolehlivou změnu v negativním směru).

V př́padě empiricky odvozených metod se očekávaný průběh terapie u daného klienta predikuje na základě údajů o jiných klientech z databáze, kteří mají podobné vstupní charakteristiky. Predikce se provádí pomocí modelů růstových křivek (Tasca \& Gallop, 2009). Je možné vypočítat konfidenční intervaly očekávané trajektorie a s jejich pomocí posuzovat, nakolik se skutečný průběh terapie odchyluje od toho předpokládaného. Spolu s tím je pak možno vypočítat i pravděpodobnost, $s$ jakou bude terapie pro daného klienta úspěšná (Castonguay et al., 2013). Pokud se skutečná trajektorie odchyluje od té očekávané v pozitivním směru, zvyšuje se pravděpodobnost úspěšné terapie, zatímco odchylky negativním směrem zvyšují riziko neúspěchu (Lutz et al., 2006). Empirický přístup se ukazuje jako účinnější než racionální (tamtéž), lze jej ale použít až ve chvíli, kdy v databázi daného systému existuje dostatečný počet dříve léčených klientů.

Existuje řada systémů, které implementují výše popsané principy do rutinního měření účinku terapie. Mezi nejznámější patří systémy OQ-Analyst, Outcome Referrals, CORE Net a Partners for Change Outcome Management System, které nyní blíže představíme.

OQ-Analyst ${ }^{4}$ je systém založený na dotazníku Outcome Questionnaire-45 (OQ-45), který svými 45 položkami pokrývá tři oblasti: distres spojený se symptomy, interpersonální problémy a fungování v sociálních rolích (Wells, Burlingame, Lambert, Hoag, \& Hope, 1996). Autoři dokládají vysoké hodnoty vnitřní konzistence i stability v čase, dobrou souběžnou i konstruktovou validitu, schopnost rozlišit mezi klinickým a neklinickým vzorkem a citlivost $\mathrm{k}$ terapeutické změně (Lambert et al., 1996). V novější verzi (OQ-45.2) dotazník navíc obsahuje také položky mapující suicidální tendence, abúzus látek a násilí na pracovišti/ve škole (Beckstead et al., 2003). Kromě tohoto dotazníku systém obsahuje také další podpůrné nástroje, které umožňují klientovi administrovat dotazník v případě, že se terapie nevyvijí podle očekávání, a terapeutovi pak nabízí

\footnotetext{
${ }^{4}$ http://www.oqmeasures.com/
} 
možnost oslovit problematické oblasti (White et al., 2015). Systém je vyvíjen komerčně a ani samotný dotazník OQ-45 není volně dostupný.

Outcome Referrals 5 je systém vystavěný na dotazníku Treatment Outcome Package (TOP). Verze pro dospělé má 58 položek, pokrývajících dvanáct empiricky odvozených domén: suicidální tendence, násilí, psychotické příznaky, deprese, abúzus látek, úzkost, mánie, poruchy spánku, fungování v práci, fungování v sociálních vztazích, sexuální fungování a kvalita života (Kraus, 2012). Autoři dokumentují jeho kvalitní psychometrické charakteristiky vč. faktorové struktury, stability v čase, konvergentní a diskriminační validity, rozlišovací schopnosti jednotlivých škál a schopnosti celého dotazníku rozlišovat mezi dysfunkční a zdravou populací (Kraus, Seligman, \& Jordan, 2005). Kromě samotného měření terapeutické změny nástroj podporuje terapeutovo vytváření formulace př́padu, komunikaci mezi klientem a terapeutem a také dokumentuje, $\mathrm{v}$ jakých oblastech či s jakými problémy se terapeutovi daří pracovat lépe a s jakými naopak hůře (Youn, Kraus, \& Castonguay, 2012). Podle následující studie se 96\% terapeutů na základě tohoto dotazníku ukázalo jako kompetentních alespoň v jedné z dvanácti sledovaných domén a žádný terapeut nebyl kompetentní ve všech (Kraus, Castonguay, Boswell, Nordberg, \& Hayes, 2011). Díky sledování efektivity terapeutů v jednotlivých doménách pak systém umožňuje vyhledávat nejvhodnější terapeuty pro daného klienta. Systém je poskytován zdarma, ale pouze v rámci Spojených států a pouze praktikům, kteří se prokáží profesní licencí. Pokud je nám známo, dotazník samotný volně dostupný není.

CORE Net ${ }^{6}$ je systém vytvořený na základě dotazníku Clinical Outcomes in Routine Evaluation - Outcome Measure (CORE-OM). Jedná se o 34položkový dotazník se čtyřmi subškálami mapujícími subjektivní pohodu, problémy/symptomy, fungování v životě a rizikové chování (Evans et al., 2000). Dotazník má dobrou vnitřní konzistenci, stabilitu v čase a konvergentní validitu, dokáže dobře rozlišovat mezi klinickým a neklinickým výběrem a vykazuje dobrou citlivost ke změně v průběhu terapie (Evans et al., 2002). Dotazník byl přeložen (nebo je v současné době překládán) do řady evropských i dalších jazyků. Existuje i v české verzi, která aktuálně prochází psychometrickým ověřováním a je dostupná na webu ${ }^{7}$ nebo u autorů tohoto článku. Systém CORE Net obsahuje i řadu dalších nástrojů a je použitelný též pro poradenská centra v rámci pracovišt' či vyššího vzdělávání. Systém lze využívat za poplatek, dotazník samotný je ale volně dostupný a může být implementován i do jiných systémů.

Partners for Change Outcome Management System ${ }^{8}$ (PCOMS) je systém založený na dvojici dotazníků Outcome Rating Scale (ORS) a Session Rating Scale (SRS). Jedná se o velmi krátké, čtyřpoložkové nástroje, z nichž první měří změnu v terapii a druhý zjišt’uje kvalitu pracovního spojenectví mezi klientem a terapeutem (Duncan, 2012;

\footnotetext{
5 http://outcomereferrals.com/

${ }^{6} \mathrm{http}: / /$ www.coreims.co.uk/

${ }^{7} \mathrm{http}: / /$ www.coresystemtrust.org.uk/

${ }^{8} \mathrm{https}: / /$ heartandsoulofchange.com/
} 
Miller, Duncan, Sorrell, \& Brown, 2005). Několik studií dokládá uspokojivé psychometrické vlastnosti obou nástrojů, které jsou kompromisem mezi standardními požadavky na psychometrické nástroje a krátkostí obou dotazníků, díky níž jsou snadno využitelné v rutinní praxi (Bringhurst, Watson, Miller, \& Duncan, 2006; Campbell \& Hemsley, 2009; Duncan, 2003; Miller, Duncan, Brown, Sparks, \& Claud, 2003). Oba nástroje jsou dostupné $\mathrm{i} v$ českém jazyce ${ }^{9} \mathrm{a}$ v současné době jsou ověřovány psychometrické vlastnosti této české verze. Od dříve zmíněných systémů se PCOMS poněkud liší svou filozofií: škály jsou administrovány během sezení a diskuze o klientových odpovědích je nedílnou součástí samotného terapeutického procesu. To sice poněkud omezuje výzkumné využití takto získaných dat (škála se stává komunikačním prostředkem mezi klientem a terapeutem a klient jejím prostřednictvím terapeutovi pravděpodobně sdělí pouze to, o čem je v danou chvíli ochoten v rámci terapie mluvit), ale maximalizuje to možnost jejich přímého klinického využití. Škály ORS a SRS jsou v současné době implementovány do dvou internetových systémů: MyOutcomes ${ }^{10}$ a FIT-Outcomes ${ }^{11}$ (FIT značí Feedback-Informed Treatment). Používání obou systémů je zpoplatněno, dotazníky jsou však volně dostupné.

Představili jsme zde pouze několik nejznámějších monitorovacích systémů, existuje jich však mnohem více. Mezi další patří např. Counseling Center Assessment of Psychological Symptoms ${ }^{12}$ (CCAPS), poskytující služby vysokoškolským poradenským centrům, systém Carepath ${ }^{13}$, určený psychiatrům, psychologům, sociálním pracovníkům a poradcům voblasti duševního zdraví, CelestHealth Solutions ${ }^{14}$, využívaný na poli poradenských i zdravotnických služeb, PROMIS15, využívající metodologii IRT (Item Response Theory) a adaptivního testování, systém OPTUM ${ }^{16}$, který zveřejňuje hodnocení terapeutů na základě efektivity jejich práce, či ACORN17. Existují také systémy vyvinuté pouze pro konkrétní pracoviště.

\section{Vliv zpětné vazby na účinnost psychoterapie}

Ve studii provedené na vzorku 50 amerických terapeutů se $90 \%$ respondentů domnívalo, že používání nástrojů měřících účinek psychoterapie je ztrátou času. Mezi ostatními možnými indikátory, jako jsou např. klinická intuice, klientem udávané zlepšení či pokrok v dosahování individuálně stanovaného cíle, se používání standardizovaných nástrojů ocitlo až na posledním místě v četnosti využívání (Garland, Kruse, \& Aarons, 2003). Empirické studie však ukazují, že zpětná vazba s použitím těchto nástrojů může mít na účinek psychoterapie pozitivní vliv.

\footnotetext{
${ }^{9}$ http://www.dalet.cz/Clanky/scales-CZ.pdf

10 http://www.myoutcomes.com/

11 https://www.fit-outcomes.com/

12 http://ccmh.psu.edu/

13 http://blog.carepaths.com/

14 http://www.celesthealth.com/

15 http://www.nihpromis.org/

16 https://www.providerexpress.com/

17 http://www.psychoutcomes.org/
} 
Několik studií ukazuje, že zpětná vazba snižuje riziko deterioračního efektu u klientů, kteří se nevyvíjí podle očekávání (tzv. not-on-track cases). Např. ve studii Lamberta et al. (2001) bylo 609 klientů univerzitního poradenského centra rozděleno do dvou skupin: v první skupině terapeuti dostávali grafickou zpětnou vazbu ohledně klientova pokroku v terapii (na základě výsledků v dotazníku OQ-45), ve druhé skupině terapeuti nedostávali žádnou zpětnou vazbu. Zpětná vazba naznačující, že klient nedělá pokroky podle očekávání, vedla $\mathrm{k}$ pozitivnějšímu výsledku v porovnání s kontrolní skupinou. Zhoršování stavu klientů se ve skupině se zpětnou vazbou objevilo pouze u $6 \%$ oproti $23 \%$ v kontrolní skupině. Obdobné výsledky přinesla i replikace této studie (Lambert et al., 2002). Metaanalýza tří studií dospěla k závěru, že implementace systému zpětné vazby snížila míru deteriorace klientů o 4 až 8\% (Lambert et al., 2003). Pozitivní vliv zpětné vazby u negativně se vyvíjejících případů potvrdila i další metaanalýza (Shimokawa, Lambert, \& Smart, 2010) a také studie mimo Lambertův tým (De Jong et al., 2014). Efekt je vyšší, je-li zpětná vazba doprovázena dalším podpůrným nástrojem, napomáhajícím terapeutovi v rozhodování, jakou intervenci v reakci na zpětnou vazbu zvolit (Whipple et al., 2003). Jedním z efektů zpětné vazby je to, že zhoršující se klienti, kteří by jinak ukončili terapii, v ní zůstávají déle (např. Lambert et al., 2001). V následující studii se ale tento efekt projevil pouze u zkušených terapeutů (Lambert et al., 2002) a nebyl metaanalýzou (Shimokawa et al., 2010) potvrzen. Udávaná velikost efektu zpětné vazby se různí: zatímco již zmíněná metaanalýza Shimokawa et al. (2010) udává velký efekt $(d=0,70)$, jiná metaanalýza (Knaup, Koesters, Schoefer, Becker, \& Puschner, 2009) uvádí efekt v podstatě zanedbatelný $(d=0,10)$. Efekt zpětné vazby byl potvrzen i řadou dalších studií publikovaných po těchto metaanalýzách (např. Simon, Lambert, Harris, Busath, \& Vazquez, 2012; Simon et al., 2013).

U klientů, u nichž se terapie vyvíjí podle očekávání (tzv. on-track cases), je evidence poněkud méně jednoznačná. $V$ některých studiích neměla zpětná vazba významný vliv na celkový efekt psychoterapie, snížila ale počet potřebných sezení (např. Lambert et al., 2001). V Lambertově replikační studii se tento efekt opět objevil pouze u zkušenějších terapeutů (Lambert et al., 2002). Metaanalytická studie dospěla k závěru, že i když efekt zpětné vazby je u těchto klientů nižší než u tzv. not-on-track klientů, vede u nich k významnému snížení distresu a častějšímu dosahování klinicky významné změny (Shimokawa et al., 2010). Výsledky několika novějších studií ale naznačují, že zpětná vazba je pro klienty efektivní, at' už se jejich terapie vyvíjí podle očekávání či nikoliv (Bickman, Kelley, Breda, de Andrade, \& Riemer, 2011) a to zejména v dlouhodobější terapii (De Jong et al., 2014). Je možné, že efekt zpětné vazby je různý pro různé populace klientů. Nižší efekty u on-track případů (tedy u těch, které se vyvíjejí podle očekávání) lze vysvětlit tím, že pozitivní zpětná vazba („vše běží podle plánu“) nevede ke změně terapeutických intervencí (Sapyta, Riemer, \& Bickman, 2005). Jiným vysvětlením by mohlo být, že $\mathrm{v}$ dlouhodobější terapii mají terapeuti více příležitostí i bez monitorovacího systému zachytit, že se stav klienta zhoršuje, a adekvátně na to reagovat (De Jong et al., 2014). 
Několik studií zkoumalo, zda je efektivnější poskytovat zpětnou vazbu pouze terapeutovi, nebo terapeutovi i klientovi současně. Některé z nich dospěly k závěru, že poskytování zpětné vazby oběma účastníkům terapeutického vztahu má vyšší efekt (De Jong, 2014; Hawkins, Lambert, Vermeersch, Slade, \& Tuttle, 2004), jiné tyto výsledky nepotvrdily (Harmon, Hawkins, Lambert, Slade, \& Whipple, 2005; Slade, Lambert, Harmon, Smart, \& Bailey, 2008).

Někteří autoři se snažili zjistit, zda je efekt zpětné vazby ovlivněn proměnnými na straně terapeuta. Ukázalo se, že klienti se rychleji zlepšují v případě terapeutů, kteří více věří standardizované zpětné vazbě než vlastnímu názoru, kteří cítí větší závazek k používání zpětné vazby a kteří mají vyšší vědomí vlastní účinnosti (De Jong, van Sluis, Nugter, Heiser, \& Spinhoven, 2012). Je ovšem potřeba upozornit, že efekt terapie je měřen stejným nástrojem, na jehož základě je také poskytována zpětná vazba - systém tedy nezachytí oblasti změny, na něž použitý dotazník není citlivý, zatímco klinik si může všímat i jiných oblastí a jeho zhodnocení klientova stavu pak může být se standardizovaným hodnocením v rozporu. $\mathrm{V}$ jiné studii se ukázalo, že pozitivnější vztah k monitorování účinku mají soukromí praktikové a ti, kteří léčí hospitalizované pacienty - ve srovnání s praktiky v ambulantních zařízeních (Smits, Claes, Stinckens, \& Smits, 2015).

Zásadním omezením dosavadních výzkumů v oblasti psychoterapie je to, že v drtivé většině pocházejí $\mathrm{z}$ jedné výzkumné skupiny organizované okolo $\mathrm{M}$. Lamberta. Nicméně přehledová studie Carlier et al. (2012), která zmapovala 52 experimentálních studií týkajících se rutinního monitorování efektu a poskytování zpětné vazby z širší oblasti tělesného a duševního zdraví, dospěla k podobně optimistickým závěrům.

\section{Některá omezení monitorovacích systémů}

Je na místě zmínit také určitá metodologická i praktická omezení zmíněných monitorovacích systémů. Mezi těmi metodologickými můžeme zdůraznit, že popsané systémy plně spoléhají na sebeposuzovací škály, které představují pouze jednu z možných perspektiv posuzování terapeutické změny (viz např. Timulák, 2005). Poměrné krátké standardizované nástroje také nemusejí dostatečně citlivě zachycovat individuální změnu daného klienta. Některé výzkumy dokumentují, že detekujeme-li změnu kvalitativními způsoby, můžeme dospět k výsledkům, které se od těch dotazníkových liší, či jsou s nimi dokonce v př́mém rozporu (Doran, 2015; Zatloukal, 2012). Považujeme tedy za užitečné uvažovat také o alternativních metodách zkoumání účinku psychoterapie, jako jsou tzv. idiosynkratické metody, v nichž si klienti sami formulují položky na základě svých potíží (např. Ashworth et al., 2005; Elliott, Mack, \& Shapiro, 1999) či kvalitativní procedury, v nichž se efekt zjišt'uje polostrukturovaným rozhovorem (Elliott \& Rodgers, 2008; Sandell, 1987). Mezi praktickými limity můžeme jmenovat např. finanční a časovou zátěž spojenou se sběrem dat, stejně jako nedůvěru kliniků v možnost měřit tak komplexní fenomén, jakým je terapeutická změna, či jejich obavy z hodnocení vlastního výkonu a srovnávání (Boswell, Kraus, Miller, \& Lambert, 2015). 


\section{Závěr}

Ve vyspělých zemích se klade velký důraz na měření efektu psychoterapeutické léčby. Ukazuje se, že monitorování účinku psychoterapie a poskytování zpětné vazby terapeutům (a klientům) může účinek psychoterapie dále zvyšovat. Monitoring účinku je součástí širšího trendu tzv. na praxi orientovaného výzkumu (Castonguay et al., 2013) a obratu k terapii založené na zpětné vazbě (Miller, Duncan, \& Hubble, 2004). Lze očekávat, že další vývoj psychoterapie se bude ubírat tímto směrem (v den dokončení tohoto článku vyšlo speciální číslo časopisu Psychotherapy Research plně věnované tomuto tématu).

Rutinní měření účinnosti a využívání zpětné vazby může mít několik pozitivních důsledků: (a) umožňuje terapeutům další profesní rozvoj skrze kontinuální zpětnou vazbu (viz např. Miller, Hubble, Chow, \& Seidel, 2013), (b) umožňuje predikovat úspěšnost terapeutické intervence $u$ daného klienta a významně snížit riziko deteriorace, (c) umožňuje vybrat vhodného terapeuta pro konkrétního klienta, (d) umožňuje posuzovat kvalitu služeb určitého pracoviště, (e) umožňuje kontinuálně získávat výzkumná data vypovídající o reálné každodenní psychoterapeutické praxi, (f) zvyšuje transparentnost psychoterapeutické profese. Domníváme se, že tyto přednosti jsou dostatečným argumentem, aby se psychoterapeuti, terapeutická pracoviště i výcvikové instituty začaly monitorováním účinku zabývat, a přispěly tak i v našem prostředí k dalšímu zkoumání jeho možností a limitů.

\section{Literatura}

Ashworth, M., Robinson, S. I., Godfrey, E., Parmentier, H., Shepherd, M., Christey, J., ... Matthews, V. (2005). The experiences of therapists using a new client-centred psychometric instrument, PSYCHLOPS (Psychological Outcome Profiles). Counselling \& Psychotherapy Research, 5(1), 37-42. doi:10.1080/14733140512331343886

Barlow, D. H. (2010). Negative effects from psychological treatments: A perspective. The American Psychologist, 65(1), 13-20. doi:10.1037/a0015643

Bergin, A. E., \& Lambert, M. J. (1978). The evaluation of therapeutic outcomes. In S. L. Garfield \& A. E. Bergin (Eds.), Handbook of psychotherapy and behavior change: An empirical analysis (2nd ed., pp. 139-189). New York, NY: John Wiley \& Sons.

Beckstead, D. J., Hatch, A. L., Lamert, M. J., Eggett, D. L., Goates, M. K., \& Vermeersch, D. A. (2003). Clinical significance of the Outcome Questionnaire (OQ-45.2). The Behavior Analyst Today, 4(1), 86-97. doi:10.1037/h0100015

Bickman, L., Kelley, S. D., Breda, C., de Andrade, A. R., \& Riemer, M. (2011). Effects of routine feedback to clinicians on mental health outcomes of youths: Results of a randomized trial. Psychiatric Services, 62(12), 1423-1429. doi:10.1176/appi.ps.002052011

Boswell, J. F., Kraus, D. R., Miller, S. D., \& Lambert, M. J. (2015). Implementing routine outcome monitoring in clinical practice: Benefits, challenges, and solutions. Psychotherapy Research, 25(1), 6-19. doi:10.1080/10503307.2013.817696 
Bringhurst, D. L., Watson, C. W., Miller, S. D., \& Duncan, B. L. (2006). The reliability and validity of the Outcome Rating Scale: A replication study of a brief clinical measure. Journal of Brief Therapy, 5(1), 23-30.

Campbell, A., \& Hemsley, S. (2009). Outcome Rating Scale and Session Rating Scale in psychological practice: Clinical utility of ultra-brief measures. Clinical Psychologist, 13(1), 19. doi:10.1080/13284200802676391

Carlier, I. V. E., Meuldijk, D., Van Vliet, I. M., Van Fenema, E., Van Der Wee, N. J. A., \& Zitman, F. G. (2012). Routine outcome monitoring and feedback on physical or mental health status: Evidence and theory. Journal of Evaluation in Clinical Practice, 18(1), 104-110. doi:10.1111/j.1365-2753.2010.01543.x

Castonguay, L. G., Barkham, M., Lutz, W., \& McAleavey, A. (2013). Practice-oriented research: Approaches and applications. In M. J. Lambert (Ed.), Bergin and Garfield's handbook of psychotherapy and behavior change (6th ed., pp. 85-133). Hoboken, NJ: John Wiley.

De Jong, K., van Sluis, P., Nugter, M. A., Heiser, W. J., \& Spinhoven, P. (2012). Understanding the differential impact of outcome monitoring: Therapist variables that moderate feedback effects in a randomized clinical trial. Psychotherapy Research, 22(4), 464-474. doi:10.1080/10503307.2012.673023

De Jong, K., Timman, R., Hakkaart-Van Roijen, L., Vermeulen, P., Kooiman, K., Passchier, J., \& Busschbach, J. Van. (2014). The effect of outcome monitoring feedback to clinicians and patients in short and long-term psychotherapy: A randomized controlled trial. Psychotherapy Research, 24(6), 629-639. doi:10.1080/10503307.2013.871079

Doran, J. M., Westerman, A. R., Kraus, J., Jock, W., Safran, J. D., \& Muran, J. C. (2015, June). Do all roads lead to Rome? A critical analysis of agreement and divergence in qualitative and quantitative descriptors of change. Poster presented at the 46th International Annual Meeting of the Society for Psychotherapy Research, Philadelphia, PA, USA.

Duncan, B. L. (2012). The Partners for Change Outcome Management System (PCOMS): The Heart and Soul of Change Project. Canadian Psychology/Psychologie canadienne, 53(2), 93104. doi:10.1037/a0027762

Duncan, B. L., Miller, S. D., Sparks, J. A., Claud, D. A., Reynolds, L. R., Brown, J., \& Johnson, L. D. (2003). The Session Rating Scale: Preliminary psychometric properties of a "working" alliance measure. Journal of Brief Therapy, 3(1), 3-12.

Elliott, R., Mack, C., \& Shapiro, D. A. (1999). Simplified Personal Questionnaire procedure. Retrieved from http://www.experientialresearchers.org/instruments/elliott/pqprocedure.html

Elliott, R., \& Rodgers, B. (2008). Client Change Interview. Retrieved from http://www.drbrianrodgers.com/research/client-change-interview

Evans, C., Connell, J., Barkham, M., Margison, F., McGrath, G., Mellor-Clark, J., \& Audin, K. (2002). Towards a standardised brief outcome measure: Psychometric properties and utility of the CORE-OM. British Journal of Psychiatry, 180, 51-60. doi:10.1192/bjp.180.1.51

Evans, C., Mellor-Clark, J., Margison, F., Barkham, M., Audin, K., Connell, J., \& McGrath, G. (2000). CORE: Clinical Outcomes in Routine Evaluation. Journal of Mental Health, 9(3), 247-255. doi:10.1080/jmh.9.3.247.255 
Garland, A. F., Kruse, M., \& Aarons, G. A. (2003). Clinicians and outcome measurement: What's the use? The Journal of Behavioral Health Services \& Research, 30(4), 393-405. doi:10.1007/BF02287427

Hannan, C., Lambert, M. J., Harmon, C., Nielsen, S. L., Smart, D. W., Shimokawa, K., \& Sutton, S. W. (2005). A lab test and algorithms for identifying clients at risk for treatment failure. Journal of Clinical Psychology, 61(2), 155-163. doi:10.1002/jclp.20108

Hansen, N. B., Lambert, M. J., \& Forman, E. M. (2002). The psychotherapy dose-response effect and its implications for treatment delivery services. Clinical Psychology: Science and Practice, 9(3), 329-343. doi:10.1093/clipsy/9.3.329

Harmon, C., Hawkins, E. J., Lambert, M. J., Slade, K., \& Whipple, J. L. (2005). Improving outcomes for poorly responding clients: The use of clinical support tools and feedback to clients. Journal of Clinical Psychology, 61(2), 175-185. doi:10.1002/jclp.20109

Hatfield, D., McCullough, L., Frantz, S. H. B., \& Krieger, K. (2010). Do we know when our clients get worse? An investigation of therapists' ability to detect negative client change. Clinical Psychology and Psychotherapy, 17(1), 25-32. doi:10.1002/cpp.656

Hawkins, E. J., Lambert, M. J., Vermeersch, D. A., Slade, K. L., \& Tuttle, K. C. (2004). The therapeutic effects of providing patient progress information to therapists and patients. Psychotherapy Research, 14(3), 308-327. doi:10.1093/ptr/kph027

Jacobson, N. S., \& Truax, P. (1991). Clinical significance: a statistical approach to defining meaningful change in psychotherapy research. Journal of Consulting and Clinical Psychology, 59(1), 12-19. doi:10.1037/0022-006X.59.1.12

Knaup, C., Koesters, M., Schoefer, D., Becker, T., \& Puschner, B. (2009). Effect of feedback of treatment outcome in specialist mental healthcare: Meta-analysis. The British Journal of Psychiatry, 195(1), 15-22. doi:10.1192/bjp.bp.108.053967

Kraus, D. R. (2012). The Treatment Outcome Package (TOP). Integrating Science and Practice, 2(2), 43-45.

Kraus, D. R., Castonguay, L. G., Boswell, J. F., Nordberg, S. S., \& Hayes, J. A. (2011). Therapist effectiveness: Implications for accountability and patient care. Psychotherapy Research, 21(3), 267-276. doi:10.1080/10503307.2011.563249

Kraus, D. R., Seligman, D. A., \& Jordan, J. R. (2005). Validation of a behavioral health treatment outcome and assessment tool designed for naturalistic settings: The treatment outcome package. Journal of Clinical Psychology, 61(3), 285-314. doi:10.1002/jclp.20084

Lambert, M. J. (2013a). Outcome in psychotherapy: The past and important advances. Psychotherapy, 50(1), 42-51. doi:10.1037/a0030682

Lambert, M. J. (2013b). The efficacy and effectiveness of psychotherapy. In M. J. Lambert (Ed.), Bergin and Garfield's handbook of psychotherapy and behavior change (6th ed., pp. 169218). Hoboken, NJ: John Wiley.

Lambert, M. J., Burlingame, G. M., Umphress, V., Hansen, N. B., Vermeersch, D. A., Clouse, G. C., \& Yanchar, S. C. (1996). The reliability and validity of the Outcome Questionnaire. Clinical Psychology and Psychotherapy, 3(4), 249-258. doi:10.1002/(sici)10990879(199612)3:4<249::aid-cpp106>3.0.co;2-s 
Lambert, M. J., \& Ogles, B. M. (2004). The efficacy and efffectiveness of psychotherapy. In M. J. Lambert (Ed.), Bergin and Garfield's handbook of psychotherapy and behavior change (5th ed., pp. 307-389). New York, NY: John Wiley.

Lambert, M. J., Whipple, J. L., Hawkins, E. J., Vermeersch, D. A., Nielsen, S. L., \& Smart, D. W. (2003). Is it time for clinicians to routinely track patient outcome? A meta-analysis. Clinical Psychology: Science and Practice, 10(3), 288-301. doi:10.1093/clipsy.bpg025

Lambert, M., Whipple, J., Smart, D., Vermeersch, D., Nielsen, S. L., \& Hawkins, E. J. (2001). The effects of providing therapists with feedback on patient progress during psychotherapy: Are outcomes enhanced? Psychotherapy Research, 11(1), 49-68. doi:10.1080/713663852

Lambert, M. J., Whipple, J. L., Vermeersch, D. A., Smart, D. W., Hawkins, E. J., Nielsan, S. L., \& Goates, M. (2002). Enhancing psychotherapy outcomes via providing feedback on client progress: A replication. Clinical Psychology and Psychotherapy, 9(2), 91-103. doi:10.1002/cpp.324

Lipsey, M. W., \& Wilson, D. B. (1993). The efficacy of psychological, educational, and behavioral treatment: Confirmation from meta-analysis. The American Psychologist, 48(12), 11811209. doi:10.1037/0003-066X.48.12.1181

Lutz, W., Böhnke, J. R., \& Köck, K. (2011). Lending an ear to feedback systems: Evaluation of recovery and non-response in psychotherapy in a German outpatient setting. Community Mental Health Journal, 47(3), 311-317. doi:10.1007/s10597-010-9307-3

Lutz, W., Lambert, M. J., Harmon, S. C., Tschitsaz, A., Schürch, E., \& Stulz, N. (2006). The probability of treatment success, failure and duration - What can be learned from empirical data to support decision making in clinical practice? Clinical Psychology and Psychotherapy, 13(4), 223-232. doi:10.1002/cpp.496

Lutz, W., Stulz, N., Martinovich, Z., Leon, S., \& Saunders, S. M. (2009). Methodological background of decision rules and feedback tools for outcomes management in psychotherapy.

Psychotherapy Research, 19(4-5), 502-510. doi:10.1080/10503300802688486

Miller, S. D., Duncan, B. L., Brown, J., Sparks, J. A., \& Claud, D. A. (2003). The Outcome Rating Scale: A preliminary study of the reliability, validity, and feasibility of a brief visual analog measure. Journal of Brief Therapy, 2(2), 91-100.

Miller, S. D., Duncan, B. L., \& Hubble, M. A. (2004). Beyond integration: The triumph of outcome over process in clinical practice. Psychotherapy in Australia, 10(2), 2-19.

Miller, S. D., Duncan, B. L., Sorrell, R., \& Brown, G. S. (2005). The Partners for Change Outcome Management System. Journal of Clinical Psychology, 61(2), 199-208. doi:10.1002/jclp.20111

Miller, S. D., Hubble, M. A., Chow, D. L., \& Seidel, J. A. (2013). The outcome of psychotherapy: Yesterday, today, and tomorrow. Psychotherapy, 50(1), 88-97. doi:10.1037/a0031097

Sandell, R. (1987). Assessing the effects of psychotherapy: III. Reliability and validity of 'Change after Psychotherapy.' Psychotherapy and Psychosomatics, 47(1), 44-52.

Sapyta, J., Riemer, M., \& Bickman, L. (2005). Feedback to clinicians: Theory, research, and practice. Journal of Clinical Psychology, 61(2), 145-153. doi:10.1002/jclp.20107

Shimokawa, K., Lambert, M. J., \& Smart, D. W. (2010). Enhancing treatment outcome of patients at risk of treatment failure: Meta-analytic and mega-analytic review of a psychotherapy quality assurance system. Journal of Consulting and Clinical Psychology, 78(3), 298-311. doi:10.1037/a0019247 
Simon, W., Lambert, M. J., Busath, G., Vazquez, A., Berkeljon, A., Hyer, K., ... Berrett, M. (2013). Effects of providing patient progress feedback and clinical support tools to psychotherapists in an inpatient eating disorders treatment program: A randomized controlled study. Psychotherapy Research, 23(3), 287-300. doi:10.1080/10503307.2013.787497

Simon, W., Lambert, M. J., Harris, M. W., Busath, G., \& Vazquez, A. (2012). Providing patient progress information and clinical support tools to therapists: Effects on patients at risk of treatment failure. Psychotherapy Research, 22(6), 638-647. doi:10.1080/10503307.2012.698918

Slade, K., Lambert, M. J., Harmon, S. C., Smart, D. W., \& Bailey, R. (2008). Improving psychotherapy outcome: The use of immediate electronic feedback and revised clinical support tools. Clinical Psychology and Psychotherapy, 15(5), 287-303. doi:10.1002/cpp.594

Smith, M. L., \& Glass, G. V. (1977). Meta-analysis of psychotherapy outcome studies. The American Psychologist, 32(9), 752-60. doi: 10.1037//0003-066X.32.9.752

Smith, M. L., Glass, G. V, \& Miller, T. I. (1980). The benefits of psychotherapy. Baltimore, MD: The Johns Hopkins University Press.

Smits, D. F., Claes, L., Stinckens, N., \& Smits, D. J. M. (2015). Clinicians' attitudes towards outcome and process monitoring: A validation of the Outcome Measurement Questionnaire.

Administration and Policy in Mental Health Services Research, 42(5), 634-641. doi:10.1007/s10488-014-0597-6

Tasca, G. A., \& Gallop, R. (2009). Multilevel modeling of longitudinal data for psychotherapy researchers: I. The basics. Psychotherapy Research, 19(4-5), 429-437. doi:10.1080/10503300802641444

Timulák, L. (2005). Současný výzkum psychoterapie. Praha: Triton.

Youn, S. J., Kraus, D. R., \& Castonguay, L. G. (2012). The treatment outcome package: Facilitating practice and clinically relevant research. Psychotherapy, 49(2), 115-122. doi:10.1037/a0027932

Wampold, B. E. (2001). The great psychotherapy debate: Models, methods, and findings. Mahwah, NJ: Lawrence Erlbaum Associates.

Wells, M. G., Burlingame, G. M., Lambert, M. J., Hoag, M. J., \& Hope, C. A. (1996). Conceptualization and measurement of patient change during psychotherapy: Development of the Outcome Questionnaire and Youth Outcome Questionnaire. Psychotherapy, 33(2), 275-283. doi:10.1037/0033-3204.33.2.275

Whipple, J. L., Lambert, M. J., Vermeersch, D. A., Smart, D. W., Nielsen, S. L., \& Hawkins, E. J. (2003). Improving the effects of psychotherapy: The use of early identification of treatment and problem-solving strategies in routine practice. Journal of Counseling Psychology, 50(1), 59-68. doi:10.1037/0022-0167.50.1.59

White, M. M., Lambert, M. J., Ogles, B. M., Mclaughlin, S. B., Bailey, R. J., \& Tingey, K. M. (2015). Using the Assessment for Signal Clients as a feedback tool for reducing treatment failure. Psychotherapy Research. Advance online publication. doi:10.1080/10503307.2015.1009862

Zatloukal, L. (2012). Komunikace v psychoterapeutické praxi a terapeutická změna (Doctoral dissertation). Retrieved from http://theses.cz/id/ays9yk/00181958-296271926.pdf 


\title{
Řiháček, T., \& Juhová, D.: \\ Outcome monitoring in psychotherapy and counseling
}

\begin{abstract}
In psychotherapy and counseling research, practice-oriented research has been gaining momentum recently. Its aim is to study the process and the outcome of psychotherapy and counseling interventions in routine practice. In the Western world, therapeutic and counseling facilities are increasingly beginning to use software systems to continually monitor the effect of treatment offered. Research evidence shows that using this outcome information as feedback has a positive impact on the effectiveness of therapy and counseling practice. In this paper, the principles upon which these systems work will be summarized, as well as the benefits and limitations of routine outcome monitoring and its implementation into practice.
\end{abstract}

Keywords: psychotherapy effectiveness, outcome monitoring, feedback, implementation 